\title{
Association of cycle threshold values of CBNAAT with severity and outcome in COVID-19
}

\author{
Kranti Garg, Karan Sharma, Aditi Gupta, Vishal Chopra \\ Department of Pulmonary Medicine, Government Medical College, Patiala, India
}

\begin{abstract}
Determination of viral load through cycle threshold $(\mathrm{Ct})$ values may act as a predictor of severity and outcomes in patients with corona virus disease 2019 (COVID-19). However, variable literature is available regarding this relationship. Our study attempted to explore this association and the effect of various socio-demographic and clinical parameters on severity and outcome of COVID-19. Retrospective analysis of records of 731 patients whose nasopharyngeal/oropharyngeal swabs were subjected to cartridge based nucleic acid amplification (CBNAAT) on Cepheid Xpert Xpress SARS-CoV-2 was done. Ct values of N2 and $\mathrm{E}$ genes were studied in relation to severity and outcome of COVID-19. The viral load as determined by $\mathrm{Ct}$ values was classified as high $(<25)$, medium $(25.1-32)$ and low $(>32)$. Association of socio-demographic and clinical parameters with respect to severity and outcome was also studied. Severity and mortality
\end{abstract}

Correspondence: Vishal Chopra, Department of Pulmonary Medicine, Government Medical College, 27 Bank Colony, Patiala, Punjab, India. Tel. +91.9814146788 .

E-mail: drvishalchopra@hotmail.com

Key words: Ct value; N2 gene; E gene; COVID-19.

Contributions: KG, substantial contributions to the conception or design of the work, analysis, and interpretation of data for the work; $\mathrm{KS}$, substantial contributions to the acquisition and analysis of data for the work; AG, drafting the work or revising it critically for important intellectual content; $\mathrm{VC}$, final approval of the version to be published. All the authors have read and approved the final version of the manuscript and agreed to be accountable for all aspects of the work.

Conflict of interest: The authors declare that they have no competing interests, and all authors confirm accuracy.

Ethical approval: taken from the Institutional Ethics Committee.

Received for publication: 3 January 2021.

Accepted for publication: 8 June 2021.

${ }^{\circ}$ Copyright: the Author(s), 2021

Licensee PAGEPress, Italy

Monaldi Archives for Chest Disease 2021; 91:1759

doi: 10.4081/monaldi.2021.1759

This article is distributed under the terms of the Creative Commons Attribution Noncommercial License (by-nc 4.0) which permits any noncommercial use, distribution, and reproduction in any medium, provided the original author(s) and source are credited. were significantly more in elder individuals, those belonging to the rural background, those with symptoms $>7$ days in duration before presentation and those with increasing number of co-morbidities (severity: $\mathrm{p}<0.001$; mortality: $\mathrm{p}<0.001,0.005,0.006$ and $<0.001$, respectively). The $\mathrm{Ct}$ values of gene $\mathrm{N} 2$ and $\mathrm{E}$ inversely correlated with severity and mortality from the disease (N2 gene: $\mathrm{p}=0.001$ for both severity and mortality, $\mathrm{E}$ gene: severity: $p<0.001$, mortality: $p=0.016$, respectively). The severity of the illness and chances of mortality were significantly lesser when the CT value of $\mathrm{N} 2$ gene was $>32$, in comparison when it was upto 25 , and when between 25.1 and 32 (severity: $p=0.032$ and 0.003 , respectively; mortality: $\mathrm{p}=0.018$ and $<0.001$, respectively). Almost similar trends were seen with respect to $\mathrm{E}$ gene (severity: $\mathrm{p}<0.001$ and 0.067 , respectively; mortality $\mathrm{p}=0.175$ and 0.005 , respectively). Viral load as determined by $\mathrm{Ct}$ values of $\mathrm{N} 2$ and $\mathrm{E}$ genes can act as surrogate markers for prediction of severity and disease outcomes in COVID-19.

\section{Introduction}

The corona virus disease 2019 (COVID-19) pandemic gripped the world with an array of uncertainties related to each and every aspect, right from the clinical presentation to diagnosis and treatment [1]. Over the months, as we proceed in the natural course of a pandemic, we are clearer regarding these aspects than we were a year ago. One such important aspect is to predict the severity and outcome of this deadly disease, as the patient is labeled as diagnosed with COVID-19.

Diagnosis of COVID-19 is usually via real-time PCR, however, we are still unclear whether determination of viral load through cycle threshold $(\mathrm{Ct})$ values at the point of diagnosis can give us any idea about the severity and outcome of the disease [2-10]. Our study is one such attempt to find if $\mathrm{Ct}$ value, particularly on cartridge based nucleic acid amplification (CBNAAT), can be relied upon to predict severity and outcome. In addition, we tried to explore the role of socio-demographic and clinical parameters in relation to the above said indicators.

\section{Materials and Methods}

It was a retrospective study where data of the patients whose samples were received for COVID-19 testing were reviewed with respect to various socio-demographic and clinical variables. The nasopharyngeal/oropharyngeal swabs taken at specimen collection centers were received in the laboratory in viral transport medium in cold chain. These samples were subjected to CBNAAT 
on Cepheid Xpert Xpress SARS-CoV-2 according to manufacturer's instructions after the advisories for the use of the same were issued [11-13]. Xpert Xpress SARS-Cov-2 detects N2 and E gene by real time polymerase chain reaction (rt-PCR) [13]. The samples reported as positive, and detecting both $\mathrm{N} 2$ and $\mathrm{E}$ genes with their respective $\mathrm{Ct}$ values were finally included in the analysis. $\mathrm{Ct}$ value is defined as the number of cycles of amplification required for the fluorescence of a PCR product to be detected crossing a threshold, which is above the background signal [14]. The samples with $\mathrm{Ct}$ values between 12 and 45 were reported as positive. Since no standard classification was available for samples subjected to CBNAAT, the viral load as determined by $\mathrm{Ct}$ values was classified as high $(<25)$, medium (25.1-32) and low (>32). The samples which gave amplification of only one gene and not the other (representing probable diagnosis) were subjected to a repeat CBNAAT/ rt-PCR to confirm the diagnosis. The patients with a report of probable diagnosis were not a part of our analysis. The Indian Council of Medical Research (ICMR) specimen referral form [15] of the patients was scrutinized and it was reviewed for their age, gender, rural/urban background, first symptom of presentation, duration and categorization as per symptomatology. The number and types of co-morbid illnesses, severity of illness as per clinical management protocol COVID-19 issued by Government of India (asymptomatic/ mild/ moderate/ severe) [16] and the final outcomes (recovery/ death) were noted. Even under the pressing circumstances of the pandemic, the process of sample collection, transportation in the cold chain, the platform which was used for detection and storage of the sample and turnaround time was uniformly maintained.

Data of a total of 756 patients was reviewed; 25 patients were shifted out/ referred from our center and their outcome could not be traced and hence were excluded from the final analysis. Thus, final analysis included 731 patients.

\section{Statistical analysis}

data was of categorical variables so was reported as counts and percentages. Group comparisons (recovered/death) were made with the Chi-Square test or Fisher's exact test. Numeric data was represented as mean $\pm \mathrm{SD}$, median and interquartile range, categories for gene N2 and gene E were calculated. A p-value $<0.05$ was considered significant. All the statistical tests were two-sided and were performed at a significance level of $\alpha=0.05$. Analysis was conducted using IBM SPSS STATISTICS (ver. 22.0).

The study was approved by the Institute's Research and Ethics committee.

\section{Results}

Records of a total of 731 patients were analyzed. Majority of the patients who presented to us were males $(63.7 \%)$ and belonged to the urban background (78.1\%). Age distribution and other sociodemographic and clinical variables are depicted in Table 1; $37.1 \%$ had fever as their first presenting symptom followed by shortness of breath in $23.8 \%$ patients. The majority $(76.9 \%)$ of the patients were from category ' $\mathrm{C} 9$ ' (in hospital-all patients of severe acute respiratory infection) as described in ICMR specimen referral form [15]. The majority $(65.3 \%)$ of the patients had no co-morbid illness. Diabetes mellitus was seen as the most common co-morbid- ity, other co-morbidities were cardiac illness (coronary artery disease, hypertension, etc.), chronic lung diseases, etc. Fifty-one percent of patients had severe disease [16] and $65 \%$ patients recovered, however $35 \%$ patients succumbed to the disease (Table 1).

The relationship of various socio-demographic and clinical variables with severity of the illness and outcome of the disease is depicted in Table 2. Severity and mortality both were significantly more in elder individuals, those belonging to the rural background,

Table 1. Socio-demographic and clinical profile.

\begin{tabular}{|c|c|c|}
\hline Variable & Categories & Number (\%) \\
\hline Age (in years) & $\begin{array}{c}<20 \\
21-30 \\
31-40 \\
41-50 \\
51-60 \\
61-70 \\
>70\end{array}$ & $\begin{array}{c}20(2.7 \%) \\
61(8.3 \%) \\
103(14.1 \%) \\
135(18.5 \%) \\
218(29.8 \%) \\
119(16.3 \%) \\
75(10.3 \%)\end{array}$ \\
\hline Gender & $\begin{array}{c}\text { Male } \\
\text { Female }\end{array}$ & $\begin{array}{l}466(63.7 \%) \\
265(36.3 \%)\end{array}$ \\
\hline Background & $\begin{array}{l}\text { Urban } \\
\text { Rural }\end{array}$ & $\begin{array}{l}571(78.1 \%) \\
160(21.9 \%)\end{array}$ \\
\hline Duration of illness & $\begin{array}{c}<7 \text { days } \\
>7 \text { days } \\
\quad \text { Nil }\end{array}$ & $\begin{array}{l}512(70.0 \%) \\
107(14.6 \%) \\
112(15.3 \%)\end{array}$ \\
\hline First presenting symptom & $\begin{array}{c}\text { Fever } \\
\text { Shortness of breath } \\
\text { Others } \\
\text { Nil }\end{array}$ & $\begin{array}{c}271(37.1 \%) \\
174(23.8) \\
174(23.8 \%) \\
112(15.3 \%)\end{array}$ \\
\hline Category* & $\begin{array}{c}2 \\
6 \\
8 \\
10 \\
12 \\
15 \\
9 \\
17\end{array}$ & $\begin{array}{c}6(0.8 \%) \\
20(2.7 \%) \\
34(4.7 \%) \\
32(4.4 \%) \\
7(1.0 \%) \\
1(0.1 \%) \\
562(76.9 \%) \\
69(9.4 \%)\end{array}$ \\
\hline Number of co-morbidities & $\begin{array}{c}0 \\
1 \\
2 \\
\geq 3\end{array}$ & $\begin{array}{c}477(65.3 \%) \\
167(22.8 \%) \\
81(11.1 \%) \\
6(0.8 \%)\end{array}$ \\
\hline Severity of disease & $\begin{array}{l}\text { Asymptomatic } \\
\text { Mild } \\
\text { Moderate } \\
\text { Severe }\end{array}$ & $\begin{array}{c}112(15.3 \%) \\
42(5.7 \%) \\
204(27.9 \%) \\
373(51 \%)\end{array}$ \\
\hline Outcome & $\begin{array}{l}\text { Recovered } \\
\text { Death }\end{array}$ & $\begin{array}{l}475(65 \%) \\
256(35 \%)\end{array}$ \\
\hline
\end{tabular}

${ }^{*}$ Category as described in ICMR specimen referral form [15].

Table 2. Relationship of socio-demographic and clinical variables with severity and outcome of the disease.

\begin{tabular}{lcc} 
Age group & $<0.001$ & $<0.001$ \\
Gender & 0.171 & 0.071 \\
\hline Rural/urban background & $<0.001$ & 0.005 \\
Duration of symptoms $(>7$ days $)$ & $<0.001$ & 0.006 \\
\hline Number of co-morbidities & $<0.001$ & $<0.001$
\end{tabular}


those with symptoms $>7$ days in duration before presentation and those with increasing number of co-morbidities (Table 2).

There was no correlation of gene N2 with age $(\mathrm{p}=0.593)$, duration of illness $(<7$ days or $>7$ days, $\mathrm{p}=0.605)$ or number of co-morbidities $(\mathrm{p}=0.644)$. The $\mathrm{Ct}$ values of gene $\mathrm{N} 2$ inversely correlated with severity of the disease as well as mortality from the disease. The severity of the disease and mortality decreased with an increase in $\mathrm{Ct}$ value. Patients with $\mathrm{Ct}$ values $\leq 25$ had significantly more chances of moderate/severe disease than those with higher $\mathrm{Ct}$ values $(p=0.001)$. Similarly, mortality was more in patients with $\mathrm{Ct}$ values $\leq 25(p=0.001)$. The severity of the illness and chances of mortality were significantly lesser when the CT value of $\mathrm{N} 2$ gene was $>32$, in comparison when it was up to 25 , and in comparison, when between 25.1 and 32 (Table 3).

On a similar trend, there was no correlation of gene $\mathrm{E}$ with age $(p=0.636)$, duration of illness $(<7$ days or $>7$ days, $p=0.513)$ or number of co-morbidities $(\mathrm{p}=0.240)$. The $\mathrm{Ct}$ values of gene $\mathrm{E}$ also correlated inversely with severity of the disease as well as mortality. The severity of the disease and mortality decreased with an increase in $\mathrm{Ct}$ value. Patients with $\mathrm{Ct}$ values $\leq 25$ had significantly more chances of having moderate/severe disease than those with higher $\mathrm{Ct}$ values $(\mathrm{p}<0.001)$. Similarly, mortality was more in patients with $\mathrm{Ct}$ values $\leq 25(\mathrm{p}=0.016)$.

Results of the Ct value of E gene inversely correlated significantly for severity when compared between 25.1 to $32 v s>32$, but not when compared between $\leq 25$ and $>32$, though severity was more with lesser $\mathrm{Ct}$ values. The $\mathrm{Ct}$ values of $\mathrm{E}$ gene inversely correlated significantly with mortality when compared between $\leq 25$ vs $>32$, but not when compared between 25.1 to 32 vs $>32$, though mortality was more with lesser Ct values (Table 4).

\section{Discussion}

Since the laboratory received nasopharyngeal/oropharyngeal swabs as per the need and urgency of reporting, it was seen that the majority of the patients were in-hospital patients of severe acute respiratory infection (C9 category) and were having moderate/severe disease. Consequently, as reflected in the outcome indicators, $35 \%$ of our patients succumbed to the illness.

The severity and outcome of the disease was significantly poorer with increasing age, in patients belonging to rural background, those with late presentation ( $>7$ days), and those with increasing number of co-morbidities. However, it had no relation with gender. Our results are in coherence with the existing literature [17,18]. World Health Organization and Ministry of Health and Family Welfare has also particularly warned for the increasing severity and poorer outcomes in these sub group of individuals, and our results supported this further [16-19]. In India, patients usually belong to rural areas and present late during the course of the disease for seeking health care, mainly because of various socio-economic and cultural beliefs. The fear of isolation of the COVID-19 positive patients and subsequent separation from their family members could be another reason for delayed presentations, resulting in an increase in severity and mortality. It needs to be emphasized that people should be sensitized extensively regarding the disease and early reporting to the health care facilities is mandatory before it gets 'too late'.

Despite differences in the current COVID-19 pandemic, our past experience of the epidemic of SARS-CoV in 2002 tells us that high viral load is associated with increased severity and poor prognosis $[20,21]$. Higher $\mathrm{Ct}$ values correlate with lower viral loads and vice-versa [20,21]. In the diagnosis of COVID-19, the real time PCR targets have varied in the previous studies available till date and included ORF1ab, N and E genes and the 5' untranslated genome region [22]. With this background knowledge, we targeted the N2 gene and the E gene, and tried to decipher this relationship of viral loads with severity and outcomes. In general, our study reported an inverse correlation of $\mathrm{Ct}$ values of both $\mathrm{N} 2$ and $\mathrm{E}$ genes with severity as well as mortality.

In this sub-classification, it was seen that the $\mathrm{Ct}$ values of $\mathrm{N} 2$ gene, could help identify the patients expected to be have a severer disease and poorer survival. If the $\mathrm{Ct}$ value of gene $\mathrm{N} 2$ was $\leq 25$, in comparison with being $>32$, the severity as well as mortality was significantly higher $(\mathrm{p}=0.003$ and $<0.001$, respectively). Asymptomatic/mild disease (lesser severity) and recovery from the illness were more if $\mathrm{Ct}$ value of $\mathrm{N} 2$ gene was $>32$ in comparison with when it was $\leq 25$. Similarly, if $\mathrm{Ct}$ value of gene N2 was

Table 3. Relationship of $\mathrm{Ct}$ values of gene $\mathrm{N} 2$ with severity and outcome of the disease.

\begin{tabular}{|c|c|c|c|c|c|c|c|c|}
\hline \multirow[t]{2}{*}{ Ct value } & \multicolumn{4}{|c|}{ Severity } & \multicolumn{4}{|c|}{ Outcome } \\
\hline & Asymptomatic & Mild & Moderate & Severe & p-value & Recovered & Death & p-value \\
\hline Up to 25 & $50(20.1 \%)$ & $15(6.0 \%)$ & $50(20.1 \%)$ & $134(53.8 \%)$ & 0.003 & $144(57.8 \%)$ & $105(42.2 \%)$ & $<0.001$ \\
\hline$>32$ & 37 (16.1\%) & $13(5.7 \%)$ & $81(35.2 \%)$ & $99(43.0 \%)$ & & $170(73.9 \%)$ & $60(26.1 \%)$ & \\
\hline $25.1-32$ & $25(9.9 \%)$ & $14(5.6 \%)$ & $73(29.0 \%)$ & $140(55.5 \%)$ & 0.032 & $161(63.9 \%)$ & $91(36.1 \%)$ & 0.018 \\
\hline$>32$ & 37 (16.1\%) & $13(5.7 \%)$ & $81(35.2 \%)$ & $99(43.0 \%)$ & & $170(73.9 \%)$ & 60 (26.1\%) & \\
\hline
\end{tabular}

Ct value, cycle threshold value.

Table 4. Relationship of $\mathrm{Ct}$ values of gene $\mathrm{E}$ with severity and outcome of the disease.

\begin{tabular}{|c|c|c|c|c|c|c|c|c|}
\hline \multirow{2}{*}{ Ct value } & \multicolumn{4}{|c|}{ Severity } & \multicolumn{4}{|c|}{ Outcome } \\
\hline & Asymptomatic & Mild & Moderate & Severe & p-value & Recovered & Death & p-value \\
\hline Upto 25 & $58(18.5 \%)$ & $19(6.1 \%)$ & 73 (23.3\%) & $163(52.1 \%)$ & 0.067 & 187 (59.7\%) & $126(40.3 \%)$ & 0.005 \\
\hline$>32$ & $33(21.3 \%)$ & $9(5.8 \%)$ & $51(32.9 \%)$ & $62(40.0 \%)$ & & $113(72.9 \%)$ & $42(27.1 \%)$ & \\
\hline $25.1-32$ & $21(8.0 \%)$ & $14(5.3 \%)$ & $80(30.4 \%)$ & $148(56.3 \%)$ & $<0.001$ & $175(66.5 \%)$ & 88 (33.5\%) & 0.175 \\
\hline$>32$ & $33(21.3 \%)$ & $9(5.8 \%)$ & $51(32.9 \%)$ & $62(40.0 \%)$ & & 113 (72.9\%) & $42(27.1 \%)$ & \\
\hline
\end{tabular}

Ct value, cycle threshold value. 
between 25.1 to 32 , then being $>32$, the severity as well as mortality was significantly higher ( $\mathrm{p}=0.032$ and 0.018 , respectively).

Using the same classification, it was also seen that if $\mathrm{Ct}$ value of gene $E$ was $\leq 25$, in comparison with being $>32$, there were higher chances of the disease being more severe, though non-significant $(p=0.067)$, and the mortality was significantly higher $(\mathrm{p}=0.005)$. However, if the $\mathrm{Ct}$ value of gene $\mathrm{N} 2$ was 25.1 to 32 , then being $>32$, the severity of the disease was significantly higher, and the mortality was also more, though statistically non-significant $(\mathrm{p}<0.001$ and 0.175 , respectively).

The results of the $\mathrm{Ct}$ value of $\mathrm{E}$ gene on a similar classification, can also help predict the similar behavior, but to a lesser extent than the N2 gene. Studies that give the quantification of viral load in clinical specimens by reporting $\mathrm{Ct}$ values are limited and quite variable [2-10]. Our results with $\mathrm{Ct}$ values being representative of the viral load in relation to the severity and mortality of the disease are consistent with some available studies [3-7]. However, at the same time, we should remember that as per the epidemiological triad model, the fine interplay of interactions between the agent, host and environment helps in deciding the course of a disease process. Severity and final outcomes are deemed to be affected by the immune status of the patients, as 'susceptible' hosts are more prone to develop infections, have severer disease and poorer outcomes. Those with stronger immune systems, despite having high viral loads (as depicted by $<25 \mathrm{Ct}$ values for $\mathrm{N} 2$ and $\mathrm{E}$ gene) can be asymptomatic or have a mild disease and so was seen in a few of our patients too. This could possibly be the reason why some other studies have failed to establish the relationship of $\mathrm{Ct}$ values with severity and mortality [8-10].

Overall, the results from our study highlight that both N2 and E gene, and in particular N2 gene can be used as a surrogate marker of severity as well as mortality. The prediction of likelihood of severity and negative outcomes at an early stage at first presentation in a clinical setting can help in making timely and strategic treatment decisions. This early knowledge of probability of progression can ultimately help in decreasing the morbidity and mortality. In a pandemic like COVID-19, where we are struggling with availability and extreme shortage of health care facilities, this early triage of the patients as per viral load can be extremely rewarding from the administrative and public health point too. Also, early detection of high-level replication of the virus can help in the early institution of anti-viral therapy, thus shortening the course of the disease, reducing severity and improving chances of survival [23].

Our study is the first of its kind, to assess the mentioned relationship between viral loads and severity/outcome, as no study on similar relationship of the samples processed on CBNAAT is available till date in English literature. The sample of more than 700 patients is another strength of our study.

\section{Limitations of the study}

Since our study was a retrospective analysis, we did not study the $\mathrm{Ct}$ values at multiple time points in the same individual during the course of illness.

\section{Conclusions}

The baseline Ct values of both N2 and E gene, and in particular $\mathrm{N} 2$ gene can provide important information in relation to severity and possible outcomes of COVID-19 and can complement the existing protocols in making tailored individualized treatment decisions. Prospective studies in this regard can help in generating more evidence in this context.

\section{References}

1. World Health Organization. Coronavirus disease (COVID-19). Accessed: 16 December 2020. Available from: https://www. who.int/emergencies/diseases/novel-coronavirus-2019

2. World Health Organization. Laboratory testing for 2019 novel coronavirus (2019-nCoV) in suspected human cases. WHO Interim guidance 2020. Available from: https://www.who.int/ publications/i/item/10665-331501

3. Zheng S, Fan J, Yu F, et al. Viral load dynamics and disease severity in patients infected with SARS-CoV-2 in Zhejiang province, China, January-March 2020: Retrospective cohort study. BMJ 2020;369:m1443.

4. Magleby R, Westblade LF, Trzebucki A, et al. Impact of SARS-CoV-2 viral load on risk of intubation and mortality among hospitalized patients with coronavirus disease 2019. Clin Infect Dis 2020; ciaa851. Online ahead of print.

5. Liu Y, Yan LM, Wan L, et al. Viral dynamics in mild and severe cases of COVID-19. Lancet Infect Dis 2020;20:656-7.

6. Eberhardt KA, Meyer-Schwickerath C, Heger E, et al. RNAemia corresponds to disease severity and antibody response in hospitalized COVID-19 patients. Viruses 2020; 12:1045.

7. Chu CM, Poon LLM, Cheng VCC, et al. Initial viral load and the outcomes of SARS. CMAJ 2004;171:1349-52.

8. Lui G, Ling L, Lai CK, et al. Viral dynamics of SARS-CoV-2 across a spectrum of disease severity in COVID-19. J Infect 2020;81:324-7.

9. Shi F, Wu T, Zhu X, et al. Association of viral load with serum biomarkers among COVID-19 cases. Virology 2020;546:122-6.

10. He X, Lau EHY, Wu P, et al. Temporal dynamics in viral shedding and transmissibility of COVID-19. Nat Med 2020;26 672-5.

11. US Food and Drug Administration. Coronavirus (COVID-19) Update: FDA Issues first Emergency Use Authorization for Point of Care Diagnostic. Accessed: 16 December 2020. Available from: https://www.fda.gov/news-events/pressannouncements/coronavirus-covid-19-update-fda-issues-firstemergency-use-authorization-point-care-diagnostic

12. Indian Council of Medical Research. Advisory Newer Additional Strategies for COVID-19 Testing. Accessed: 16 December 2020. Available from: https://www.icmr.gov.in/pdf/ covid/strategy/Advisory_for_rapid_antigen_test_14062020.pdf

13. Cepheid. Xpert ${ }^{\circledR}$ Xpress SARS-CoV-2 - Instructions for Use. Accessed: 16 December 2020. Available from: https://www.fda.gov/media/136314/download

14. Public Helath Ontario. An overview of cycle threshold values and their role in SARS-CoV-2 real-time PCR test interpretation. 2020. Available from: https://www.publichealthontario.ca//media/documents/ncov/main/2020/09/cycle-threshold-valuessars-cov2-pcr.pdf?la=en

15. Indian Council of Medical Research. ICMR Specimen Referral Form for COVID-19 (SARS-CoV2). Available from: https://www.icmr.gov.in/pdf/covid/labs/SRF_v12.pdf

16. Ministry of Health and Family Welfare. Clinical management protocol: COVID-19. Version 3. 2020. 
17. Guan WJ, Liang WH, He JX, et al. Cardiovascular comorbidity and its impact on patients with COVID-19. Eur Respir J 2020;55:2001227.

18. Zhou F, Yu T, Du R, et al. Clinical course and risk factors for mortality of adult inpatients with COVID-19 in Wuhan, China: a retrospective cohort study. Lancet 2020;395:1054-62.

19. World Health Organization. Clinical Management of COVID19 - Interim guidance. Available from: https://apps.who.int/ iris/bitstream/handle/10665/332196/WHO-2019-nCoV-clinical-2020.5-eng.pdf? sequence $=1$ \&isAllowed $=\mathrm{y}$

20. Geddes L. Puzzle over viral load. New Sci 2020;245:8.
21. Ng EKO, Hui DS, Chan KCA, et al. Quantitative analysis and prognostic implication of SARS coronavirus RNA in the pasma and serum of patients with severe acute respiratory syndrome. Clin Chem 2003;49:1976-80.

22. Rao S, Manissero D, Steele VR, Pareja J. A narrative systematic review of the clinical utility of cycle threshold values in the context of COVID-19. Infect Dis Ther 2020;9:573-86.

23. Peiris JSM, Chu CM, Cheng VCC, et al. Clinical progression and viral load in a community outbreak of coronavirus-associated SARS pneumonia: A prospective study. Lancet 2003;361:1767-72. 